\title{
Seedlings of alpine species do not have better frost-tolerance than their lowland counterparts
}

\author{
Sergey Rosbakh $^{1}$ (D) $\cdot$ Vera Margreiter $^{2} \cdot$ Bernardica Jelcic $^{1,3}$
}

Received: 9 March 2020 / Accepted: 13 June 2020 / Published online: 20 June 2020

(c) The Author(s) 2020

\begin{abstract}
In contrast to adult plants, little is known about the frost-tolerance of seedlings of alpine species, despite the fact that frost has been considered as one of the main factors limiting plant recruitment in high elevation. Here we report the results of a comparative study on seedling frost-tolerance of nine congeneric species pairs with lowland (0-900 $\mathrm{m}$ a.s.1.) and alpine (1800-2700 m a.s.1.) distribution. Similarly to adult alpine plants, we expected seedlings of alpine species to be more frosttolerant than their lowland counterparts. Frost-tolerance was estimated under laboratory conditions by exposing seedlings to frost events from -1 to $-9{ }^{\circ} \mathrm{C}$, calculated as the temperature at which $50 \%$ of the seedlings were lethally damaged by frost $\left(\mathrm{LT}_{50}\right)$. The $\mathrm{LT}_{50}$ values varied between -1.95 and $-6.11^{\circ} \mathrm{C}$ suggesting that seedling of all tested species could potentially survive mild and/or short frosts, but might be lethally damaged by severe and/or continuous frost events. The $\mathrm{LT}_{50}$ values for lowland and alpine species did not differ statistically and were on average $-3.96 \pm 0.18{ }^{\circ} \mathrm{C}$ and $-4.16 \pm 0.43^{\circ} \mathrm{C}$, respectively. These findings did not confirm our hypothesis that seedlings of alpine species have higher frost-tolerance than seedlings of lowland species. Four possible reasons could explain this pattern. They include (1) comparable levels of negative-stress in both lowland and alpine habitats, (2) opportunistic seed germination strategy in alpine plants, (3) peculiarities of our experimental set up and (4) potentially stronger effects of drought on alpine seedling survival than frost.
\end{abstract}

Keywords Alps $\cdot$ Freezing $\cdot$ Frost tolerance $\cdot$ Lowland $\cdot$ Seedling

\section{Introduction}

Harsh climatic conditions in alpine environments can negatively affect the sexual reproduction success in plants of those habitats (Sakai and Larcher 1987; Körner 1999). Short growing seasons with low temperatures coupled with frequent frost events limit growth and regeneration in all plant life stages, from gametophyte development to seedlings and

Electronic supplementary material The online version of this article (https://doi.org/10.1007/s00035-020-00237-4) contains supplementary material, which is available to authorized users.

Sergey Rosbakh

sergey.rosbakh@ur.de

1 Chair of Ecology and Conservation Biology, University of Regensburg, Regensburg, Germany

2 Department of Botany, University of Innsbruck, Innsbruck, Austria

3 Department of Plant Nutrition, Faculty of Agriculture, University of Zagreb, Zagreb, Croatia adult plants (Körner 1999). Plants' exposure to sub-zero temperatures, even for short periods, can result in damages of generative organs (Larcher and Wagner 2004), considerable reduction in fruit production (Inouye 2008; Gerdol et al. 2013) or complete crop failure, and seedling mortality (Shen et al. 2014; Bianchi et al. 2019). Thus, the sensitivity of early life stages in plants is the major limiting factor in upper distributional boundaries along elevation gradients (Loik and Redar 2003; Taschler and Neuner 2004; Larcher et al. 2010; Rosbakh and Poschlod 2015).

To minimize negative effects of frost on sexual reproduction, alpine plants have developed a number of adaptations. One adaptation to low-temperature stress is delayed flowering phenology. Compared to lowland plants, alpine plants tend to flower when the frost probability is comparatively low, in mid or late summer (Inouye 2008; Bucher et al. 2019). Furthermore, particular plant growth forms such as cushion plants or low-stature are adaptations facilitating sexual reproduction, because the flowers of such plants are located very close to the ground, where local thermic conditions are much more favourable 
to fertilization and seed maturation than the corresponding macro-habitat (Körner 1999; Geiger et al. 2009). In addition to these adaptations, alpine plant generative organs (e.g., anthers, style and ovules) have been shown to tolerate freezing temperatures as low as $-5{ }^{\circ} \mathrm{C}$ (Sakai and Larcher 1987; Neuner et al. 2013). Considering further sexual reproduction phases, seed maturation of alpine plants, such as Saxifraga moschata (Ladinig and Wagner 2005) and Gentianella germanica (Wagner and Mitterhofer 1998) has been observed to be insensitive to low temperature exposure, partly due to the protecting role of snow cover (Neuner 2014; Neuner et al. 2020). Many highelevation plants produce dormant seeds to postpone germination from the year of dispersal until the next summer, encouraging the rapid onset of germination after snowmelt (Schwienbacher et al. 2011; Baskin and Baskin 2014). Such seeds contain a dehydrated embryo that is able to survive to temperatures as low as $-19{ }^{\circ} \mathrm{C}$ (Sakai and Larcher 1987; Marcante et al. 2012). Several studies have reported that germination in alpine species is triggered by higher temperatures when compared to their lowland counterparts (Rosbakh and Poschlod 2015; Picciau et al. 2019), at least in temperate climates. This 'avoidance strategy' is a way of preventing early-spring germination, when there is a high probability of seedlings being injured by frost (Cavieres and Arroyo 2000; Rosbakh and Poschlod 2015; Mondoni et al. 2018).

Following germination, seedling survival represents another major bottleneck to species recruitment (Fenner and Thompson 2005). Dormant alpine seeds are highly frost-tolerant, but this tolerance is quickly lost with the onset of germination (Sakai and Larcher 1987; Marcante et al. 2012). Consequently, seedling survival of a frost event depends on mitigating freezing risks, the ability to recover from frost damage, or tolerating frost (Sakai and Larcher 1987). Frost mitigation in alpine seedlings can be partially achieved by adapting the germination timing from early to late spring or early summer, when the probability of extreme frost events is low (Cavieres and Arroyo 2000; Rosbakh and Poschlod 2015; Mondoni et al. 2018). However, extreme frost events can still occur, even during putatively favourable periods for growth and establishment (Körner 1999), thereby putting the seedlings at risk of being killed by frost (Meyer and Badaruddin 2001; Forbis 2003; Marcante et al. 2012; Sierra-Almeida and Cavieres 2012). Recuperation via undamaged belowground organs is almost impossible in seedlings, due to their low accumulation of dry matter in the roots necessary to cope with unfavourable conditions (Körner 1999; Meyer and Badaruddin 2001; Marcante et al. 2012; Sierra-Almeida and Cavieres 2012). Therefore, tolerating frost might be the only freezing-survival option for a seedling. This point still remains to be tested, since the available research on this matter is limited to only a few case studies (Sakai and Larcher 1987; Marcante et al. 2012; Sierra-Almeida and Cavieres 2012).

The specific aim of the present study was to determine frost-tolerance of alpine seedlings sensu stricto, young plants with cotyledons but no true leaves, and compare their frost-tolerance to frost-tolerance of their lowland counterparts. The study also aims to give a clearer understanding of the adaptations employed in alpine plant reproduction at low temperatures. Our a priori assumption was that seedlings of alpine species are more frost-tolerant than seedlings from lowland species, as it is the case in adult alpine plants (Sakai and Larcher 1987; Loik and Redar 2003; Taschler and Neuner 2004). As suggested by Marcante et al. (2012) under certain circumstances frost hardening may be possible in seedlings, allowing them to adapt to frost-events. In nature, this process might take place already at temperatures slightly above $0{ }^{\circ} \mathrm{C}$ (Sakai and Larcher 1987). The alternative hypothesis was that seedlings from alpine and lowland species do not differ in their frost-tolerance, since seedlings were noted to not follow such elevation gradient patterns in terms of their frost-tolerance (Loik and Redar 2003; Briceño et al. 2014), and species from both habitats have the same chance of experiencing spring/summer frost-events (Vitasse et al. 2017; Rosbakh et al. 2017; Bianchi et al. 2019).

\section{Materials and methods}

\section{Study species and seedling material}

A comparative study using congeneric pairs of species with contrasting habitat preferences was conducted to investigate whether seedling performance co-vary predictably with habitat. Nine pairs of congeneric species with contrasting elevation distributions (lowland and alpine), were selected (Table 1). Each pair contains an independent replicate of evolutionary divergence in habitat specialization (ten Brink et al. 2012). Selected lowland species are naturally distributed in a range from 0 to $900 \mathrm{~m}$ above sea level (m a.s.1.), whereas the alpine species have their main distribution from 1700 to $2800 \mathrm{~m}$ a.s.l. The seeds were obtained from two commercial seed suppliers (Rieger-Hofmann GmbH, Germany, and Schutz Filisur Samen und Pflanzen AG, Switzerland). According to suppliers, the mother plants were cultivated under natural conditions at elevations typical for each species. Seeds were collected at maturity; after collection, seeds were air-dried for several days and stored, dry at $4{ }^{\circ} \mathrm{C}$, prior to experiments.

Seeds of Anthoxanthum alpinum, A. odoratum, and of Luzula multiflora, L. lutea, were cold-stratified in Petri dishes lined with moist filter paper at $4{ }^{\circ} \mathrm{C}$ for 6 weeks to overcome physiological dormancy. To produce enough seedlings for the experiment, 5000-6000 seeds per species were 
Table 1 Data on focal species including elevation ranges, distribution patterns, seed collecting sites and frost-tolerance $\left(\mathrm{LT}_{50}\right)$

\begin{tabular}{|c|c|c|c|c|c|c|}
\hline \multirow[t]{2}{*}{ Species } & \multirow[t]{2}{*}{ Family } & \multirow{2}{*}{$\begin{array}{l}\text { Species eleva- } \\
\text { tional ranges (m } \\
\text { a.s.1.) }\end{array}$} & \multirow[t]{2}{*}{ Distribution pattern } & \multirow[t]{2}{*}{ Seed collection site } & \multicolumn{2}{|c|}{$\begin{array}{l}\text { Seedling LT50 } \\
\left({ }^{\circ} \mathrm{C}\right)\end{array}$} \\
\hline & & & & & Estimate & SE \\
\hline Achillea millefolium $\mathrm{L}$ & Asteraceae & $0-900$ & Lowland & $\begin{array}{l}\text { Baden-Württemberg, } 400 \text { m } \\
\text { a.s.1., Germany }\end{array}$ & -3.80 & 0.93 \\
\hline $\begin{array}{l}\text { Achillea millefolium ssp. alpes- } \\
\text { tris (Wimm. and Grab.) Gremli }\end{array}$ & & $900-2000$ & Alpine & $\begin{array}{l}\text { Plan Grond, } 2050 \mathrm{~m} \text { a.s.l., } \\
\text { Switzerland }\end{array}$ & -3.09 & 0.55 \\
\hline Anthoxanthum odoratum $\mathrm{L}$ & Poaceae & $0-900$ & Lowland & $\begin{array}{l}\text { Baden-Württemberg, } 400 \text { m } \\
\text { a.s.l., Germany }\end{array}$ & -5.28 & 0.18 \\
\hline $\begin{array}{l}\text { Anthoxanthum alpinum A. et D. } \\
\text { Löve }\end{array}$ & & $2200-2800$ & Alpine & Furka, $2450 \mathrm{~m}$ a.s.1., Switzerland & -4.65 & 0.17 \\
\hline Dianthus carthusianorum L & Caryophyllaceae & $0-900$ & Lowland & $\begin{array}{l}\text { Baden-Württemberg, } 400 \text { m } \\
\text { a.s.l., Germany }\end{array}$ & -1.95 & 0.29 \\
\hline Dianthus sylvestris Wulf & & $1700-2800$ & Alpine & $\begin{array}{l}\text { Glatthorn, } 2581 \mathrm{~m} \text { a.s.l., Swit- } \\
\text { zerland }\end{array}$ & -2.52 & 0.11 \\
\hline Lotus corniculatus $\mathrm{L}$ & Fabaceae & $0-900$ & Lowland & $\begin{array}{l}\text { Baden-Württemberg, } 400 \mathrm{~m} \\
\text { a.s.1., Germany }\end{array}$ & -3.18 & 0.13 \\
\hline Lotus alpinus Schleich. ex Ram & & $2200-2800$ & Alpine & Monte Baldo, $2000 \mathrm{~m}$ a.s.l., Italy & -3.62 & 0.09 \\
\hline Luzula multiflora (Retz.) Lej & Juncaceae & $0-900$ & Lowland & $\begin{array}{l}\text { Baden-Württemberg, } 400 \mathrm{~m} \\
\text { a.s.1., Germany }\end{array}$ & -5.04 & 0.13 \\
\hline Luzula lutea (All.) DC & & $2200-2800$ & Alpine & $\begin{array}{l}\text { Glatthorn-Kastelberg, } 2200 \mathrm{~m} \\
\text { a.s.1., Switzerland }\end{array}$ & -4.06 & 0.18 \\
\hline Phleum phleoides (L.) Karst & Poaceae & $0-1000$ & Lowland & $\begin{array}{l}\text { Baden-Württemberg, } 400 \mathrm{~m} \\
\text { a.s.1., Germany }\end{array}$ & -5.70 & 0.23 \\
\hline Phleum alpinum $\mathrm{L}$ & & $2200-2800$ & Alpine & $\begin{array}{l}\text { Ravais, } 2400 \mathrm{~m} \text { a.s.1, Switzer- } \\
\text { land }\end{array}$ & -6.11 & 0.14 \\
\hline Plantago lanceolata $\mathrm{L}$ & Plantaginaceae & $0-900$ & Lowland & $\begin{array}{l}\text { Baden-Württemberg, } 400 \mathrm{~m} \\
\text { a.s.l., Germany }\end{array}$ & -2.48 & 0.10 \\
\hline Plantago alpina $\mathrm{L}$ & & $2200-2800$ & Alpine & $\begin{array}{l}\text { Zermatt-Schwarzsee, } 2585 \mathrm{~m} \\
\text { a.s.l., Switzerland }\end{array}$ & -2.94 & 0.10 \\
\hline Poa pratensis $\mathrm{L}$ & Poaceae & $0-900$ & Lowland & $\begin{array}{l}\text { Baden-Württemberg, } 400 \text { m } \\
\text { a.s.l., Germany }\end{array}$ & -4.68 & 0.23 \\
\hline Poa alpina $\mathrm{L}$ & & $1700-2800$ & Alpine & $\begin{array}{l}\text { Grossglockner, } 2260 \mathrm{~m} \text { a.s.l., } \\
\text { Austria }\end{array}$ & -5.73 & 0.16 \\
\hline Silene vulgaris (Moench) Garke & Caryophyllaceae & $0-900$ & Lowland & $\begin{array}{l}\text { Baden-Württemberg, } 400 \mathrm{~m} \\
\text { a.s.l., Germany }\end{array}$ & -3.50 & 0.10 \\
\hline Silene glareosa Jord & & $1600-2500$ & Alpine & $\begin{array}{l}\text { Val Zuondra, } 2400 \mathrm{~m} \text { a.s.1., } \\
\text { Switzerland }\end{array}$ & -3.66 & 0.10 \\
\hline
\end{tabular}

Seeds were obtained from a commercial supplier. Estimates on $\mathrm{LT}_{50}$ (temperature when $50 \%$ of seedlings were lethally damaged) derive from non-linear Weibull functions

$S E$ standard error

sown in Petri dishes on two layers of filter paper, which were moistened with distilled water. Seedlings were cultivated in a climate chamber $\left(22 / 14^{\circ} \mathrm{C}\right)$ until they reached the appropriate developmental stage for further treatments (fully developed cotyledons and radicles, just before the emergence of the first true leaf). The photoperiod was set to $16 / 8 \mathrm{~h}$, representing light conditions that the seedlings experience in nature after germination in late spring/early summer (Schwienbacher et al. 2011). The onset and duration of the seedling stage differed among the target species, but was synchronistic between two species of a congeneric pair.

\section{Experimental design, frost treatment}

Prior to the frost treatment, seedlings were incubated in a climate chamber at $6 / 0{ }^{\circ} \mathrm{C}(16 / 8 \mathrm{~h}$ photoperiod) for 3 days, to allow them to acclimate to cold conditions. Frost treatments were conducted using freezing chambers operated by a manual temperature controller SIKA R38 (Ingenieurbüro Heino Winter GmbH \& Co.). During treatments, seedlings were kept in parafilm-sealed Petri dishes lined with moist filter paper to prevent frost desiccation. Natural frost events of different severity $(0,-1,-2,-3,-4,-5,-6,-7,-8$, 
$-9{ }^{\circ} \mathrm{C}$ ) were simulated by slow cooling of the Petri dishes from $10{ }^{\circ} \mathrm{C}$ downwards, at a rate of $2 \mathrm{~K} \mathrm{~h}^{-1}$, until the target temperature was reached (Bucher et al. 2019). Thereafter, samples were kept at target temperatures for $4 \mathrm{~h}$, which is similar to durations of freezing events in nature (Sakai and Larcher 1987; Taschler and Neuner 2004; Neuner 2014). Following the same procedure as freezing, thawing was induced at a rate of $2 \mathrm{~K} \mathrm{~h}^{-1}$ until the original temperature was reached. Each temperature level was repeated three times with ten seedlings of each species. Three additional Petri dishes containing ten seedlings of each species were kept in a climate chamber at $22 / 14{ }^{\circ} \mathrm{C}(16 / 8 \mathrm{~h}$ photoperiod $)$, and another three Petri dishes in a laboratory refrigerator at $-26{ }^{\circ} \mathrm{C}$, for the same period of time as the frost treatment. The seedlings in these two treatments were used as references for fully viable and completely frost-damaged seedlings, respectively.

\section{Seedling viability}

After the frost treatment, the Petri dishes containing the seedlings were put in a climate chamber $\left(22 / 14{ }^{\circ} \mathrm{C}, 16 / 8 \mathrm{~h}\right.$ photoperiod) for $96 \mathrm{~h}$, to allow frost damage to develop. Due to comparatively low sizes, seedling viability was then determined by visual inspection; seeds with undamaged roots and vivid green coloured healthy-looking cotyledons that were able to continue growing, were considered as being viable.

\section{Statistical analysis}

Frost-tolerance was estimated as the temperature at which $50 \%$ of the seedlings were lethally damaged by frost $\left(\mathrm{LT}_{50}\right)$. To obtain these values, non-linear Weibull functions (Ritz 2010) were fitted to the cumulative binary data (1-viable seedling, 0-dead seedling) for all replicates and test temperatures for each species. Model fitting was carried out using the $d r c$ package (Ritz and Streibig 2005) in R software version 3.6. ( $\mathrm{R}$ core development team 2018). The comparison between the $\mathrm{LT}_{50}$ values of alpine and lowland species was done with linear mixed-effect models implemented in the packages lme4 (Bates et al. 2015) and lmerTest (Kuznetsova et al. 2014). To account for genus-specific variation in the $\mathrm{LT}_{50}$ values, genus was included as a random effect into the model (Funk et al. 2015). In all cases, the model requirements and assumptions were met.

\section{Results and discussion}

In contrast to adult plants (Sakai and Larcher 1987; Taschler and Neuner 2004; Neuner 2014), little is known about the frost-tolerance of seedlings, despite the fact that frost has been considered as one of the main causes of seedling mortality in high-elevation habitats (Forbis 2003; Marcante et al. 2012; Sierra-Almeida and Cavieres 2012). In this regard, our study is a small, yet an important contribution to research on plant sexual reproduction success in high elevation habitats.

Seedling frost-tolerance $\left(\mathrm{LT}_{50}\right)$ values (Fig. 1; Table 1; see also Online Appendix 1 for frost-tolerance data and fitted curves) varied in temperatures ranging between $-1.95{ }^{\circ} \mathrm{C}$ (Dianthus carthusianorum) and $-6.11{ }^{\circ} \mathrm{C}$ (Phleum alpinum). Phleum congeners were found to be the most frosttolerant species with $\mathrm{LT}_{50}$ of $-5.70{ }^{\circ} \mathrm{C}$ in the lowland $P$. phleoides and $-6.11{ }^{\circ} \mathrm{C}$ in $P$. alpinum. The most frostsusceptible congeneric pair was lowland $D$. carthusianorum $\left(\mathrm{LT}_{50}\right.$ of $\left.-1.95^{\circ} \mathrm{C}\right)$ and alpine D. sylvestris $\left(\mathrm{LT}_{50}\right.$ of $-2.52{ }^{\circ} \mathrm{C}$ ). These results suggest that seedlings of all the species tested could potentially survive mild and/or short frosts, especially when protected by standing crop and plant litter. Nevertheless, they might be lethally damaged by severe and/or continuous frost events (Marcante et al. 2012; Sierra-Almeida and Cavieres 2012).

\section{Seedling frost-tolerance in alpine vs. lowland seedlings}

On average, $\mathrm{LT}_{50}$ values for lowland and alpine species were $-3.96 \pm 0.18{ }^{\circ} \mathrm{C}$ and $-4.16 \pm 0.43{ }^{\circ} \mathrm{C}$, respectively. The comparison of the $\mathrm{LT}_{50}$ values revealed no differences ( $p=0.308$, linear mixed-effect model) in seedling frosttolerance between lowland and alpine species. These findings confirm our alternative hypothesis: seedlings of alpine species do not have higher frost-tolerance than seedlings of lowland species. Supporting this hypothesis, previous works also noted no clear elevation pattern of frost-tolerances of seedlings (Loik and Redar 2003; Brizeño et al. 2012). Therefore, we suggest discarding the expectation of alpine seedlings to be more frost-tolerant than lowland seedlings. We propose four possible reasons that could explain this pattern.

(1) First, plants from lowland and alpine habitats are equally affected and constrained by low-temperature stress. Alpine habitats are widely assumed to be harsher than lowland habitats (Körner 1999), in regard that lower temperatures are generally unfavourable for growth, and frequent freezing events can happen throughout the year (Sierra-Almeida and Cavieres 2012; Neuner 2014). However, recent studies suggested that the freezing of vegetative tissues down to $-10{ }^{\circ} \mathrm{C}$ occur more often at lower elevations than higher elevations, due to reduced snow cover and earlier snowmelt in lowlands (Rosbakh et al. 2017; Bianchi et al. 2019). Therefore, seedlings of lowland and alpine plants require similar frost-tolerance to harsh climatic conditions at least during the months in spring and early summer. 

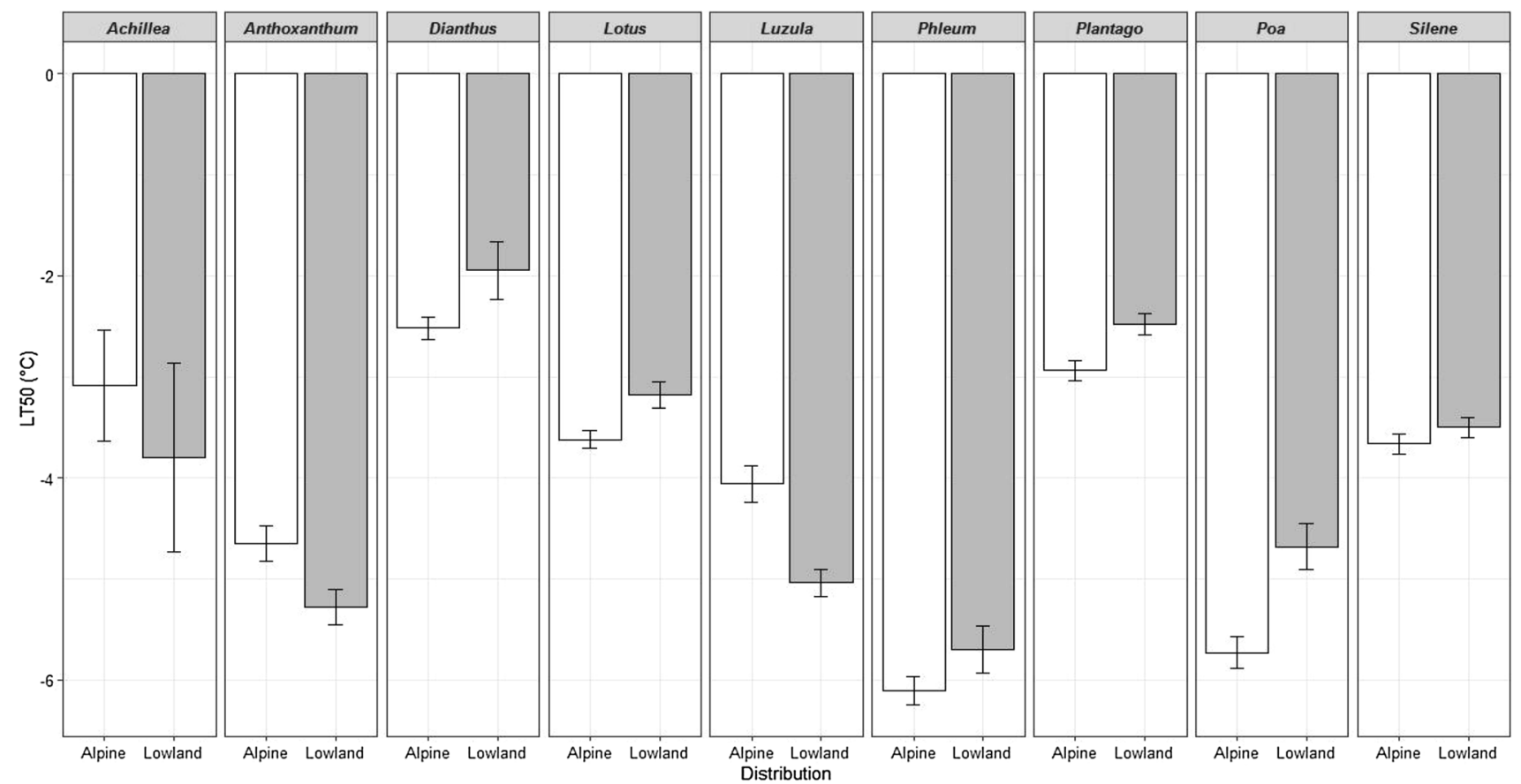

Fig. 1 Frost-tolerance $\left(\mathrm{LT}_{50}\right)$ of congeneric species pairs from different elevation origin (Distribution). Error bars indicate Standard Error. For species names see Table 1

(2) Secondly, frost survival depends not only on frosttolerance, but also on frost avoidance strategies (Taschler and Neuner 2004; Marcante et al. 2012). Since the seedling stage is the most vulnerable time in the plant life cycle, the ecological theory suggests that the germination timing is the strongest denominator of plant life (Grubb 1977; Grime 2002). Therefore, germination should optimally occur only when the subsequent environmental conditions allow growth and establishment of juveniles. The need of breaking physiological dormancy by cold stratification before germination (Schwienbacher et al. 2011), coupled with high minimum germination temperatures in alpine habitats, ensure emergence only after the risk of frost has declined, increasing the chances of seedling survivorship (Rosbakh and Poschlod 2015). This opportunistic strategy of alpine species could explain the lack of better frost-tolerance in alpine seedlings compared to their lowland counterparts.

(3) The third explanation for non-significant $\mathrm{LT}_{50}$ differences might be found in the experimental setup itself.

Previous research suggested that cold acclimation of seedlings could already take place at temperatures near $0{ }^{\circ} \mathrm{C}$ within a few days (Sakai and Larcher 1987), but the comparatively short vernalisation period in our study $\left(72 \mathrm{~h}\right.$ at $6 / 0{ }^{\circ} \mathrm{C}, 16 / 8 \mathrm{~h}$ photoperiod) might not have been cold or long enough for frost hardening to develop. As shown in a study on seedlings of Arte- misia tridentata, cold acclimation has been seen, but the determination happened after a period of 14 days (Loik and Redar 2003), much longer than the period in our study. In a comparative study of frost-resistance on juvenile plants tested in an alpine glacier foreland, field grown individuals had lower $\mathrm{LT}_{50}$ values (about $-2{ }^{\circ} \mathrm{C}$ ) than individuals cultivated in the laboratory (Marcante et al. 2012). This suggests that frost hardening under natural conditions might force seedlings to develop a higher frost-tolerance. If we had used a longer vernalisation period and/or lower temperatures, the results might have been different.

(4) Finally, frost is not the only factor determining seedling survival in alpine habitats (Marcante et al. 2012). Seedling mortality during the growing season may be caused by seedlings vulnerability to drought conditions, equally or more than by extreme cold temperatures (Söyrinki 1938; Welling and Laine 2000; Forbis 2003; Marcante et al. 2012). We speculate that due to limited resources, seedlings of alpine plants tend to invest more in drought-tolerance than in frost-tolerance. Yet, this remains to be investigated.

Acknowledgements Open Access funding provided by Projekt DEAL. We thank Madlaina Goetz for the help with the seedling frost-tolerance measurements. Comments of three anonymous reviewers helped to improve the first version of the manuscript. 
Author contributions SR conceived the idea and experimental setup, the data were collected by SR and BJ, all authors contributed equally to manuscript writing.

Funding Financial support was partially provided by the BayHost (BJ). VM received funding from the David and Claudia Harding Foundation, as part of the "Alpine Seed Conservation and Research Network".

Availability of data and material Data are available on request.

\section{Compliance with ethical standards}

Conflict of interest Authors declare no conflict of interest.

Code availability Data are available on request.

Open Access This article is licensed under a Creative Commons Attribution 4.0 International License, which permits use, sharing, adaptation, distribution and reproduction in any medium or format, as long as you give appropriate credit to the original author(s) and the source, provide a link to the Creative Commons licence, and indicate if changes were made. The images or other third party material in this article are included in the article's Creative Commons licence, unless indicated otherwise in a credit line to the material. If material is not included in the article's Creative Commons licence and your intended use is not permitted by statutory regulation or exceeds the permitted use, you will need to obtain permission directly from the copyright holder. To view a copy of this licence, visit http://creativecommons.org/licenses/by/4.0/.

\section{References}

Baskin CC, Baskin JM (2014) Seeds: ecology, biogeography, and evolution of dormancy and germination. Academic Press, Burlington

Bates D, Machler M, Bolker BM, Walker SC (2015) Fitting linear mixed-effects models using lme4. J Stat Softw 67:1-48. https:// doi.org/10.18637/Jss.V067.I01

Bianchi E, Bugmann H, Bigler C (2019) Early emergence increases survival of tree seedlings in Central European temperate forests despite severe late frost. Ecol Evol 9:8238-8252. https://doi. org/10.1002/ece3.5399

Briceño VF, Harris-Pascal D, Nicotra AB et al (2014) Variation in snow cover drives differences in frost resistance in seedlings of the alpine herb Aciphylla glacialis. Environ Exp Bot 106:174-181. https://doi.org/10.1016/j.envexpbot.2014.02.011

Bucher SF, Feiler R, Buchner O, Neuner G, Rosbakh S, Leiterer M, Römermann C (2019) Temporal and spatial trade-offs between resistance and performance traits in herbaceous plant species. Environ Exp Bot 157:187-196. https://doi.org/10.1016/j.envex pbot.2018.10.015

Cavieres LA, Arroyo MTK (2000) Seed germination response to cold stratification period and thermal regime in Phacelia secunda (Hydrophyllaceae) - altitudinal variation in the mediterranean Andes of central Chile. Plant Ecol 149:1-8. https://doi. org/10.1023/a:1009802806674

Fenner M, Thompson K (2005) The ecology of seeds. Cambridge University Press, Cambridge

Forbis TA (2003) Seedling demography in an alpine ecosystem. Am J Bot 90:1197-1206. https://doi.org/10.3732/ajb.90.8.1197
Funk JL, Rakovski CS, Macpherson JM (2015) On the analysis of phylogenetically paired designs. Ecol Evol 5:940-947. https://doi. org/10.1002/ece3.1406

Geiger R, Aron RH, Todhunter P (2009) The climate near the ground. Rowman \& Littlefield Publishers, Lanham

Gerdol R, Siffi C, Iacumin P, Gualmini M, Tomaselli M (2013) Advanced snowmelt affects vegetative growth and sexual reproduction of Vaccinium myrtillus in a sub-alpine heath. J Veg Sci 24:569-579. https://doi.org/10.1111/j.1654-1103.2012.01472.x

Grime JP (2002) Plant strategies, vegetation processes, and ecosystem properties. John Wiley \& Sons, New York

Grubb PJ (1977) The maintenance of species-richness in plant communities: the importance of the regeneration niche. Biol Rev 52:107-145. https://doi.org/10.1111/j.1469-185X.1977.tb01347.x

Inouye DW (2008) Effects of climate change on phenology, frost damage, and floral abundance of montane wildflowers. Ecol 89:353362. https://doi.org/10.1890/06-2128.1

Körner C (1999) Alpine plant life, functional plant ecology of high mountain ecosystems. Springer, Berlin

Kuznetsova A, Brockhoff PB, Christensen RHB (2014) lmertest package: tests in linear mixed effects models. J Stat Softw. https ://doi.org/10.18637/jss.v082.i13

Ladinig U, Wagner J (2005) Sexual reproduction of the high mountain plant Saxifraga moschata Wulfen at varying lengths of the growing season. Flora 200:502-515. https://doi.org/10.1016/j. flora.2005.06.002

Larcher W, Wagner J (2004) Lebensweise der Alpenrosen in ihrer Umwelt: 70 Jahre ökophysiologische Forschung in Innsbruck. Berichte des Naturwissenschaftl.-Medizin. Ver Innsbr 91:251-291

Larcher W, Kainmuller C, Wagner J (2010) Survival types of high mountain plants under extreme temperatures. Flora 205:3-18. https://doi.org/10.1016/j.flora.2008.12.005

Loik ME, Redar SP (2003) Microclimate, freezing tolerance, and cold acclimation along an elevation gradient for seedlings of the Great Basin Desert shrub, Artemisia tridentata. J Arid Environ 54:769-782. https://doi.org/10.1006/jare.2002.1106

Marcante S, Sierra-Almeida A, Spindelböck JP, Erschbamer B, Neuner G (2012) Frost as a limiting factor for recruitment and establishment of early development stages in an alpine glacier foreland? J Veg Sci 23:858-868

Meyer DW, Badaruddin M (2001) Frost tolerance of ten seedling legume species at four growth stages. Crop Sci 41:1838-1842. https://doi.org/10.2135/cropsci2001.1838

Mondoni A, Orsenigo S, Müller JV, Carlsson-Graner U, JiménezAlfaro B, Abeli T (2018) Seed dormancy and longevity in subarctic and alpine populations of Silene suecica. Alp Bot 128:71-81

Neuner G (2014) Frost resistance in alpine woody plants. Front Plant Sci 5:654. https://doi.org/10.3389/fpls.2014.00654

Neuner G, Erler A, Ladinig U, Hacker J, Wagner J (2013) Frost resistance of reproductive tissues during various stages of development in high mountain plants. Physiol Plant 147:88-100. https://doi.org /10.1111/j.1399-3054.2012.01616.x

Neuner G, Huber B, Plangger A, Pohlin JM, Walde J (2020) Low temperatures at higher elevations require plants to exhibit increased freezing resistance throughout the summer months. Environ Exp Bot 169:103882. https://doi.org/10.1016/j.envexpbot.2019.103882

Picciau R, Pritchard HW, Mattana E, Bacchetta G (2019) Thermal thresholds for seed germination in Mediterranean species are higher in mountain compared with lowland areas. Seed Sci Res 29:44-54. https://doi.org/10.1017/s0960258518000399

Ritz C, Streibig JC (2005) Bioassay analysis using R. J Stat Softw 12:1-22 
Rosbakh S, Poschlod P (2015) Initial temperature of seed germination as related to species occurrence along a temperature gradient. Funct Ecol 29:5-14. https://doi.org/10.1111/1365-2435.12304

Rosbakh S, Leingartner A, Hoiss B, Krauss J, Steffan-Dewenter I, Poschlod P (2017) Contrasting effects of extreme drought and snowmelt patterns on mountain plants along an elevation gradient. Front Plant Sci 8:1478. https://doi.org/10.3389/fpls.2017.01478

Sakai A, Larcher W (1987) Frost survival of plants. Responses and adaptation to freezing stress. Springer-Verlag, Berlin

Schwienbacher E, Navarro-Cano JA, Neuner G, Erschbamer B (2011) Seed dormancy in alpine species. Flora 206:845-856. https://doi. org/10.1016/j.flora.2011.05.001

Shen W, Zhang L, Liu XS, Luo TX (2014) Seed-based treeline seedlings are vulnerable to freezing events in the early growing season under a warmer climate: evidence from a reciprocal transplant experiment in the Sergyemla Mountains, southeast Tibet. Agr For Meteorol 187:83-92. https://doi.org/10.1016/j.agrfo rmet.2013.12.004

Sierra-Almeida A, Cavieres LA (2012) Summer freezing resistance of high-elevation plant species changes with ontogeny. Environ Exp Bot 80:10-15. https://doi.org/10.1016/j.envexpbot.2012.01.009

Söyrinki N (1938) Studien über die generative und vegetative Vermehrung der Samenpflanzen in der alpinen Vegetation PetsamoLapplands. Drück-AG Finn Lit 11:1-311
Taschler D, Neuner G (2004) Summer frost resistance and freezing patterns measured in situ in leaves of major alpine plant growth forms in relation to their upper distribution boundary. Plant Cell Environ 27:737-746. https://doi.org/10.1111/j.1365-3040.2004.01176.x

ten Brink D-J, Hendriksma HP, Bruun HH (2012) Habitat specialization through germination cueing: a comparative study of herbs from forests and open habitats. Ann Bot 111:283-292. https://doi. org/10.1093/aob/mcs253

Wagner J, Mitterhofer E (1998) Phenology, seed development, and reproductive success of an alpine population of Gentianella germanica in climatically varying years. Bot Acta 111:159-166. https ://doi.org/10.1111/j.1438-8677.1998.tb00691.x

Welling P, Laine K (2000) Characteristics of the seedling flora in alpine vegetation, subarctic Finland, I. Seedling densities in 15 plant communities. Ann Bot Fenn 37:69-76

Publisher's Note Springer Nature remains neutral with regard to jurisdictional claims in published maps and institutional affiliations. 